\title{
WestVirginiaUniversity
}

THE RESEARCH REPOSITORY @ WVU

Faculty \& Staff Scholarship

3-20-1991

\section{Social Planning and the Problems of Old Age}

Roger A. Lohmann

West Virginia University, roger.lohmann@mail.wvu.edu

Follow this and additional works at: https://researchrepository.wvu.edu/faculty_publications

Part of the Civic and Community Engagement Commons, Gerontology Commons, Public Affairs Commons, Public Policy Commons, Social Policy Commons, Social Welfare Commons, Social Work Commons, and the Urban Studies and Planning Commons

\section{Digital Commons Citation}

Lohmann, Roger A., "Social Planning and the Problems of Old Age" (1991). Faculty \& Staff Scholarship. 2567.

https://researchrepository.wvu.edu/faculty_publications/2567

This Article is brought to you for free and open access by The Research Repository @ WVU. It has been accepted for inclusion in Faculty \& Staff Scholarship by an authorized administrator of The Research Repository @ WVU. For more information, please contact ian.harmon@mail.wvu.edu. 


\section{Social Planning And The Problems of Old Age ${ }^{1}$ \\ Roger A. Lohmann \\ West Virginia University}

\section{Introduction}

Social planning is an important part of the development of the social work profession. A crucial segment of social workers continue to practice in this area, even though it has been an area of relative neglect in the professional literatures of both aging and social work in recent years. In this chapter, we will examine some basic approaches to social planning, with particular attention to the issue of community planning of services for the aged.

Planning in general can be defined as a process of preparing a set of decisions for action in the future to achieve a set of goals by optimal means (Dror, 1963). As such, the planning process is an elective one, often associated with the administration of a program or agency, and which usually occurs in the early stages of a large undertaking or enterprise, such as the creation of the original Aging Network in the 1960s, or at the beginning of a new phase of development, such as the introduction of Area Agencies on Aging in the 1970's. In the first instance, planning is a prelude to strategic or structural decision-making on "critical decisions", through which the basic direction and domain of the enterprise are established, and programs are operationalized (Selznick, 1953). In the second instance, a planning process is engaged to deal with specific identified and targeted problems - shortcomings in performance, gaps in service, programmatic failures or the need for reform.

Both types of planning are evident in the field of aging services. American society, like numerous others in the developed world has been engaging for several decades with the task of developing entirely new social institutions and practices to respond to the unprecedented growth of the elderly population which has occurred in recent decades. From slightly more than four percent of the total population in 1900, those over 65 now represent more than ten percent of the population and the figure is expected to keep increasing until 2050. And social planning is one of the primary arenas in which that adaptive struggle has been carried forward.

There are many excellent discussions of social planning theory available (Morris and Binstock, 1966; Kahn, 1969; Friedmann, 1973; Mayer, 1972 and Lauffer, 1978). Most social planning theory is built, implicitly or explicitly, on rational problem-solving models which social work students will typically be familiar with. Therefore, we will not delve deeply into theory in this

1 Part of this paper was presented at the Third International Symposium on Universal Values and Indigeneous Cultures, Morgantown WV. March 20, 1991. 
discussion. Instead, we will focus upon selected issues with implications for the planning of aging services.

One of the most widely known aspects of contemporary social planning theory is the tripartite distinction of community practice into three distinct approaches: locality development, social action and social planning (Rothman, 1979). This set of distinctions, which appears to have made its way into many introductory social work texts, is somewhat misleading in fashioning social planning as the abstract, intellectual and rationalist alternative to direct action and the remote, detached or elitist alternative to hands-on neighborhood or client involvement. In reality, effective social planning necessarily incorporates both effective social action and widespread involvement.

Social welfare planning is a term that is sometimes used to distinguish social planning in which the outcomes are presumed to be social agencies, programs or services. Innovations in housing for the elderly, retirement communities, tax exemptions and adjustments and support groups are among the many non-program or service outcomes of aging related planning. Program planning is another term for such efforts - the assessment of social needs in a population, efforts to meet those needs through coordinated deployment of resources and on-going evaluation of the results of planned intervention. Likewise, the term planned change is sometimes used to focus attention on the results of planning efforts.

One of the fundamental distinctions in contemporary planning theory is John Friedmann's differentiation of allocative and innovative planning (Friedmann, 1973). Allocative planning is concerned with allocation of money, resources or other scarce valuables among alternatives, while innovative planning is most concerned with identifying new possibilities and expanding the range of alternatives. Both have been factors in recent social planning efforts in the area of aging services. Even the most routine budget decisionmaking, for example, associated with grant awards and renewals usually involves some degree of allocative planning, while periodic initiatives expanding the range of community services like the "social invention" of hospice programs, the implementation of III-C nutrition programs or the gradual shift of III-B programs toward community based services constitute innovative planning enterprises.

Social planning is problem-solving on a large scale, or to use a popular cliche, "macro" level problem solving. In the case of social welfare planning, this is most likely to involve changes in organizational goals, legal or functional reforms, or alteration of attitudes and values in a population (Morris and Binstock, 1966). Social planning oriented toward social structural change may involve changing the membership of a group or class; changing its roles, or redefining its statuses (Mayer, 1972). Social planning may also involve planned replacement of the population in a territory or 
development of a regional socio-economic infrastructure. Both of these approaches came into play, for example, in the planning of the Appalachian Regional Commission (Hansen, 1969). Unfortunately, as the cases of Appalachia and rural America generally demonstrate, large-scale population shifts can have the effect of concentrating and exascerbating the problems of the least mobile population groups such as the old, who may be left behind while younger caregivers and support groups move away (U.S. Commission on Rural Poverty, 1965).

Why do we engage in social planning? The reasons can be many and varied. Alfred Kahn identified 10 major social planning tasks including: translating social goals into effective programs; coping with major social problems; introducing social (nonmarket) considerations; responding to gaps, fragmentation and other failures in service programs; redesigning services to meet the intended "target population"; reviewing the viability of selected fields; responding to inconsistencies and diffuseness in service strategies; allocating scarce resources; promoting the migration of concepts from one field of social welfare to another; and absorbing new technology (Kahn, 1969, $1-11)$.

\section{Planning Is Not Just a Method}

Social planning is sometimes characterized as one of a repertory of social work methods. Although it is certainly possible to discuss social planning as methodology to do so misses some very fundamental points. Community practice in general and social planning in particular do not fit easily into the type of methods approaches popular in social work education. When we speak of "social work methods" what usually comes to mind is a set of unique and integrated skills and techniques of intervention whose use is unique to social work and guided by practice principles and values of the profession. The "methods" of community practice in general and social planning in particular are, by no means, exclusive to the social work profession, but are instead the general methods of group and public problem-solving through discussion, debate and decision-making utilized generally in democratic communities.

Education for social planning and more generally community practice is more amenable to historical and comparative approaches emphasizing the complex interplay of actual organizational, political and economic forces in real situations. Social planning is, as the definition above suggests, most fundamentally a process of preparing for decision-making (i.e., action). It is the planning situation prior to decision making and not any unique planning methods (i.e. problem-solving) which most often distinguish the planning enterprise from other efforts and activities.

There is - or should be - elements of planning preceding decision-making at all levels of social work practice. Recently, there has been recognition of planning in the case management process, for example (Seldon, 1995). The 
ubiquity of planning at various levels of social work activity, however, should not be confused with the distinctive phenomenon of social planning. That which we call "social planning" is best understood as the problem-solving which precedes recognizably "big" or critical decisions and "big", that is, supraindividual, client units (For a classic discussion of "critical decisions" see Selznick, 1953). Because of this characteristic, social planning is what might be termed an extraordinary rather than a routine, ordinary, everyday approach to practice, and that explains its relative decline in recent years, as well as the shifts in emphasis noted below. Planning is not needed when routines and established practices are sufficient and unproblematic.

The process of social planning is also generally dialectical and recursive: That is, planning ordinarily involves a phase of "planning the planning" in which the problems to be solved are prioritized, and the aspects of planning to be emphasized are identified. In some cases, for example, defining the problem virtually constitutes the entire planning challenge. In other cases, definition is safely ignored, and much attention is devoted to prioritizing alternatives or identifying resources.

The structure of the planning process has interested many scholars in recent years. Nearly every social planning discussion in the past several decades has begun with some discussion of the structure of the planning process, and many published accounts are devoted primarily to this topic. Neil Gilbert (1979), for example, asks what are the implications of alternative planning structures for decision-making processes and outcomes?

\section{Community, State and Organization:}

\section{A Brief History of Social Planning}

Social work interest in planned change and the deliberate, planful modification of social relations and institutions is relatively recent. It has its origins in the Progressive ideas of social reform and progress (Commager, 1967). The intellectual and practical origins of social planning ideas and practices in social welfare can be traced directly to three distinct groups, or circles, of "reform darwinists" operating during the Progressive Era in the United States and England. The term circles is to be preferred here since in each case the tighter integration suggested by the term group was not always present. These were people who knew of and influenced one another without necessarily being in close or constant contact.

In each case, social planning was no mere abstraction or academic parlor game, but an integral component of an approach which mixed theoretical speculation and actual practice. Each was also what would today be called a "generalist" approach in which "micro" interventions with individuals and families were mixed with community development, direct social action and basic social research as circumstances dictated. 
There was a Chicago circle, or loosely affiliated group, included Jane Addams, George Herbert Mead, John Dewey and W.I. Thomas and numerous other social workers and sociologists (Deegan, 1988; Dewey, 1933; Janowitz, 1966). W.I. Thomas, for example, wrote that "the problem of social reconstruction is to create new schemes of behavior - new rules of personal conduct and new institutions - which will supplant or modify the old schemes and correspond better to the changed attitudes, that is, which will permit the latter to express themselves in action and at the same time will regulate their active manifestations so as not only to prevent the social group from becoming disorganized but to increase its cohesion by opening new fields for social cooperation."

This group operated principally out of the Hull House settlement, other Chicago-area settlements (notably the University Settlement) and the Department of Sociology at the University of Chicago. To them, we owe some of the key concepts including a dynamic, processual view of society as a changing set of relationships and the model of general problem-solving, which links together planning, decision-making and evaluation. Although Dewey is most frequently cited as the source of the problem-solving model, this approach was widely shared among the Chicago pragmatists, and is ultimately tracable to the original founder of American pragmatism, Charles Sanders Pierce (Dewey, 1933). The dynamism discussed in Dewey's article on the "Reflex Arc" concept, for example, published in 1898, is at the heart of the planning-decision making-evaluation cycle as well as the contemporary model of a "feedback loop" in so-called "systems theory."

A second group is here labeled the London circle. At the core of the London circle were Beatrice and Sidney Webb, leaders of the Fabian Socialists and relentless campaigners for municipal reform and industrial democracy (MacKenzie and MacKenzie, 1977). The Fabian emphasis on local and practical reform, like safe water supplies and sanitation, is the basis of both the community emphasis in social planning and the concept of social planning as a component of comprehensive community planning. The role of social components in comprehensive urban planning is most extensively developed by Mayer, 1985 .

In addition, a New York circle was also important in the evolution of social planning. Important figures in the New York circle were Robert deForest, John Glenn, Homer Folks, Mary Richmond and others working at the intersection of the Charity Organization Society movement and the Russell Sage Foundation. No adequate account of the community practice contributions of the Russell Sage circle currently exists, although the 2volume history of the Foundation is still insightful reading today (Glenn, et. al., 1948).

Like the Chicago social planning circle, the Russell Sage Foundation circle also was important in the emergence of the social work profession, had a 
clear and well-developed conception of planned change and was aware of the full range of intervention possibilities even while they distinguished between "wholesale" reform efforts such as social planning and the "retail" reform of relief and casework. For them, the difference was a strategic choice. The polarization of method specialization in social work was left for others. Interestingly, each of these three groups was open to valuable, even critical, contributions by both male and female participants, and the Chicago circle centered around Hull House was open to the possibilities of racial and ethnic diversity as well.

Aging planning, of course, was not a specialized concern of any of the early reform darwinists or Progressives. The aged were still a small proportion of the total population ( $4.6 \%$ in 1900); epidemics of communicable diseases were still rampant and there were few effective treatments or cures for any of the chronic diseases, so intervention beyond comfort and caring was largely futile; and family responsibility was still the official policy of the poor lawinspired local relief system which put major emphasis on public caring for the aged only as a last resort.

The first evidence of a changing position of the aged, and of major social planning activity for the aged, comes in the 1920's. The social historian Roy Lubove, who has also tracked yet another circle in Pittsburgh, has traced the growth of state level concerns with the growing problems of income maintenance of the aged through the 1920's which led up to the national social security program in the 1930's (Lubove, 1968). Although state governments universally lacked the financial resources to deal effectively with income maintenance issue on their own, this period marked the beginnings of an important historical transition of planning from the voluntary sector of the community to the government. Herbert Hoover's theories of "association government" developed in the decades before he became President in 1928 are an important element of this same set of dynamics that have been largely obscured to history because of Hoover's misguided, even catastropic, mishandling of the federal response to the stock market crash of 1929 and the ensuing economic depression of the 1930s.

\section{The Depression, Fascism, Public Planning And the Totalitarian Planning Model}

The depression of the 1930's was a period of dashed hopes and unrecognized achievements for social planning. Just as importantly, Soviet, five-year plans, the Nazi "Final Solution" and Italian and Spanish fascism in general, also provoked a profound and long-lasting "anti-planning reaction against large-scale public planning on the political right which still endures today (Hayek, 1944 [2007]; Von Mises, 1949; Machen, 1988). Hayek's original 
opposition had two important qualifiers: He objected to economic planning by the central government. Thus:

The most significant fact about this [price] system is the economy of knowledge with which it operates, or how little the individual participants need to know in order to be able to take the right action. In abbreviated form, by a kind of symbol, only the most essential information is passed on and passed on only to those concerned. It is more than a metaphor to describe the price system as a kind of machinery for registering change, or a system of telecommunications which enables individual producers to watch merely the movements of a few pointers, as an engineer might watch the hands of a few dials, in order to adjust their activities to changes of which they may never know more than is reflected in the price movement (Hayek, 1948, 85-6).

Domestically, the Tennessee Valley Authority was a broad-scale attempt at regional economic planning (Streib, 1984). Internationally, communism and fascism introduced broad new connotations of economic planning as state-control, and in reaction the notion grew up in some circles that all forms of planning (except, of course, "strategic planning" by market-oriented corporations!) were antithetical to freedom, despite the narrower focus of Hayek's critique.

There were at least two national social planning efforts affecting the aged during the 1930's which have gone largely unnoticed in the social planning literature. Planning of the Social Security system was of a very sophisticated planning enterprise, in which the detailed implications of the social insurance concept were operationalized, including the remarkable actuarial tables that are at the heart of the system. Realizing the commitment to the social insurance principle meant planning and implementing a self-financing system based upon a perpetual network of intergenerational transfers - what neo-liberal opponents love to call the "Ponzi scheme" of the system. Planners of Social Security had to work out a demographically-based, actuarially sound employer/employee tax system as well as a system of national registration of workers and adequate control of payouts. They had the demographic advantage of course, that knowledge of the number of live births, a pre-set retirement age, and predictions of the proportion of "premature" deaths considerably simplifies the challenge. Even so, all of this had to be accomplished within a set of rigorous constitutional, legal and political constraints while resisting attempts of some Congressmen to turn the program into a vehicle of political patronage.

At the same time, planned implementation of Old Age Assistance and other programs of the state-federal public assistance system which largely replaced the local relief system during the depression is another major undocumented planning activity (Lohmann, 1977). In this case, state and 
federal planners had to work out a miriad of administrative details and build an entirely new state and local assistance bureaucracy. In both cases, although they were in fact highly innovative at the time, the planning efforts involved were largely allocative in nature - concerned largely with the necessary financial arrangements and the redistribution of assets.

\section{Community Planning and Postwar Affluence}

In the two decades after the second world war, social work interest in social planning was closely linked to the expanding voluntary "community chest" (later, United Way) or health and welfare council movement (Harper and Dunham, 1959). In its most common form as federations of associations aspiring to represent entire communities, these United Way-type entities typically embrace two distinct components with planning implications: a fund-raising organization ("the campaign committee") and an allocative planning organization (sometimes called "the admissions and allocations process"). Needs assessment, resource analysis, review of alternatives, priority determination, program development and a range of other social planning techniques are frequently employed in this context.

Well before there was an Administration on Aging, a variety of prototypical aging programs, in particular senior citizens' clubs or membership associations and senior activity centers, were planned and implemented through such voluntary sector means. An associated practice innovation which evolved during this period was the "demonstration grant" in which a foundation would fund a community association or agency to work out and implement a program or service with particular promise. This model of planning was later incorporated into the original older Americans Act.

The post war era also saw the decline of the European colonial empires and the emergence of social planning in the entirely new guise of guiding the social structural changes of the emerging new nations. Interest in national social and economic "community development" emerged in the United Nations and the international agriculture community in this period. Closely associated with national transitions away from colonialism in Asia and Africa, the international community development movement drew little attention among domestically oriented social workers in the United States. Also in the post war period two other types of social planning evolved which have had important consequences for contemporary social planning efforts in social work. Both are very different from what many social workers associate with social planning,

In the late 1940's, Congress created the Council of Economic Advisors, and set in motion a limited form of national economic planning for a capitalist economy directed at changes in key economic indicators rather than empirical changes in social and economic institutions. Such planning is, by its every 
nature, "conservative" foregoing an interest in structural change and only seeking to measure fluctuations in an intact set of economic institutions. Several important social social indicators emerged from this planning effort, including the unemployment rate and more recently the poverty rate and the Retired Couple's Budget which may be the most important age-related economic indicator of this type.

The postwar housing boom in the United States also set in motion the need for a second set of local planning institutions with implications for aging. So-called "physical planning" or land-use planning directed at regulating new suburban growth and urban redevelopment gradually evolved into "comprehensive urban planning" (Friedan and Morris, 1968; Mayer, 1972; Mayer, 1985 ). The existing U.S. system of housing for the elderly was one of several major products of this particular comprehensive planning effort.

\section{Planned Social Change}

A generalized resurgence of interest in social planning arose in the social sciences during the 1960's around the concept of "planned change" (e.g., Bennis, Benne, Chin and Corey, 1976 is the third edition of a work first published in 1961). The planned change orientation is heavily grounded in a behavioral science perspective which places great emphasis on distinguishing between "basic" social sciences such as sociology and psychology and "applied" social sciences like social work. The role of practice (including planning) in this perspective is to apply the basic scientific insights developed and tested by the basic sciences. This is a dramatically different concept of social science from that shared by the reform darwinists discussed above. To its adherents, the planned change orientation suggested an entirely new relationship between government and the social sciences, patterned after the "research and development" orientation of scientists and engineers in the defense and space industries.

One such application was the development of the "opportunity theory" of poverty from the Ford Foundation financed Grey Areas Project directed at prevention of juvenile delinquincy in the early 1960's, and its subsequent application in the war on poverty through the Economic Opportunity Act of 1964 (Marris and Rein, 1967). The planned change movement was predicated on an underlying political triangle of action-oriented social scientists in universities, their colleagues in control of a range of social programs (including portions of the Administration on Aging) in the federal bureaucracy and an informal caucus of liberal Congressmen, supportive of funding for these "new welfare" programs. It has had little genuine appeal outside these rather narrow boundaries. 


\section{The New Laissez Faire}

The years since 1972 have not been kind to American social planning. Many of the federal programs supporting social planning practice have been eliminated or drastically scaled back, and individual organizations have had to rely increasingly on their own resources to plan. As a result, social planning practice today resembles social planning practice in 1950, in that it is largely restricted to the initiatives of individual organizations and local communities. At the same time, the rising popularity of "strategic planning" -with its implicit organizational focus is also a clear indicator of a major shift in the locus of social planning efforts. The trend is distinctly away from the community as a locus of planning attention, in favor of planning directed at enhancing the position and resources of individual organizations.

\section{Contemporary Social Planning Practice and Aging}

\section{Community Planning Councils}

Probably the oldest intact social planning systems for aging in most American communities today are the networks of community planning which grew up in the voluntary sector in the period after World War II. Usually a federation of member social agencies and community leaders, with fundraising and planning components, such entities go by a variety of names including "Community Councils", "Community Chests." In some cases, these local planning systems have established subcommittees on aging, long-term care or community care to deal particularly with aging issues. During the 1960 's and 1970 's, at least six additional aging-related planning systems grew up. Although little is left of most of them today, they are still worth noting.

\section{Aging Network}

With the creation of Area Agencies on Aging in the 1970's, an entire national planning network was created for the planning of aging services (Lohmann, 1978; Lohmann, 1981). Up to that point, funding decisions for AoA funds had been largely centralized in state offices of aging. The AAA amendment introduced a new level of processing in the substate regions as well as a somewhat standardized process of initiation, review and approval of project proposals. The resulting system was often cumbersome, redundant, and never involved very large sums of money, but it did result in creating at least the vestiges of a standardized service delivery system for the aged in local communities across the country.

Some of the other objectives of the early system were not quite so durable. For example, in the early 1970's, the Senior Centers - which were first established in the 1940s - were to become a "focal point" for aging services in local communities. Although they may be that in some small and rural communities, in larger urban communities where most of the elderly live, the focal point strategy has been decidedly 
unsuccessful in dealing with the problems of service coordination and control. In general, the larger and more complex the service delivery system, the more likely it is that the "focal point" strategy has been ineffective.

The Aging Network, complete with what has to be one of the most arcane bureaucracies imaginable, remains largely in place today. However, its role is almost entirely limited to delivering existing services. Its planning phases are almost entirely a thing of the past.

\section{Title XX}

Approximately at the same time as the initiation of the AoA regionalization strategy, Congress also enacted an amendment to the Social Security Act adding the twentieth title (or chapter). Medicare was Title 18 and Medicaid Title 19. Title 20, usually denoted as Title XX, and now the Community Services Block Grant program, is noteworthy from a planning standpoint for three reasons:

1. It took advantage of the open-ended nature of Congressional allocations to the states through the public assistance process, in which statematching funds were the only practical limitation on program spending.

2. It embraced "deinstitutionalization" of children, the mentally ill, retarded, and old as a national policy objective. This was part of a cluster of related policy changes which occured at the time. At the same time, the Older Americans Act was amended to increase the emphasis on community and inhome services as alternatives to nursing homes; the Developmental Disabilities Act to encompass the concept of "normalization" and the Community Mental Health Centers Act embraced the concept of community support systems for the mentally ill. Together, they add up to a planned movement away from an "indoor relief" strategy dating from the 1830's and a return to "outdoor relief" - or in more contemporary terms, community and in-home services.

3. Title XX also consolidated broad ranging financial support for children's services and aging services into a single title, thereby setting up, at least locally for agencies supported by Title XX funds, the spectre of agepolitics and competition between needy children and the old for services.

The creation of the Social Services Block Grant out of Title XX in the mid-1980's shifted the locus of planning as well as the politics of intergenerational conflict to the state agency level.

\section{Health Planning Act}

Unlike most other social planning occurring in the 1960's and 1970's, state health planning made explicit and effective, even if controversial, provision for implementation. The "certificate of need" was an approval issued by state 
health planners to new programs and services which fell within the largely statistical guidelines established for the state. Thus, new home health services or nursing homes could be developed only after a state level review in which it was determined that the number of such services had not already exceeded allowable limits and a "certificate of need" had been issued.

This gave state administrators who were in a position to make use of it (and not all were) a strong weapon to encourage development of community based services. In at least one state, for example, a ban on new nursing home construction has been in effect for nearly a decade, but states even as local community attempts to beef up community and in home services have been hamstrung by limited funding availability.

\section{Service Reorganization Initiative}

Some of the planned changes of the 1970's were largely symbolic, although they were frequently presented in the name of enhancing effectiveness and efficiency. For example, many states changed the names of their "public welfare" agencies to the more neutral euphemism of "human services," and the social work literature largely followed suit; the term "social work administration" virtually disappeared from professional vocabulary, for example, and was replaced by "human services administration". Such shifts, however superficial they may appear, are a stable and long-established aspect of symbolic policy in our field. In the same way that "public welfare" was abandoned, it had replaced the earlier term "public assistance" which, in turn, had replaced "public relief".

The more substantive part of the service reorganization initiatives of the 1970 's however, were the pattern of bringing aging, health and social services and income assistance programs of various sorts together under a single umbrella agency with titles like "Department of Health and Human Services". This was, perhaps, a set of belated state legislative responses to the creation of the umbrella department of Health, Education and Welfare in the 1950's, and mirrored directly by the federal devolution of the Department of Education out of HEW in the 1980's.

\section{Policy Institutes}

Since the mid-1960's, a portion of the burden of gerontological social policy planning in the U.S. has been borne by independent or free standing policy institutes engaged in applied research and policy analysis activity. Such work is typically conducted under contract for federal or state agencies.

The policy institute is a kind of merger of the demonstration grant strategy with the university-based or free-standing research and development group. The Brookings Institution, perhaps the grandmother of this model, the Urban Institute and the Institute for Research on Poverty at 
the University of Wisconsin; the Institute for Interdisciplinary Studies (now Interstudy) in Minneapolis, which planned the HMO Amendment to Medicare and the Heller School at Brandeis University which developed the SHMO (social health maintenance organization), and work on the OARS done at the Duke Medical Center are among many examples of such effort.

The policy institute approach to social planning offers a number of advantages for public officials. One of the advantages which this approach offers is trained, technical specialists not burdened with daily administrative responsibilities and distractions to examine policy options and alternatives on a sustained basis. Another indisputable advantage for public officials is that independent contracted policy planning is easily ignored or discounted when that is politically convenient or necessary. On the down side, the emphasis on expertise in such policy-making also contributes to corresponding decreases in community and client participation in decisionmaking.

\section{Long-Term Care Policy Initiatives}

Beginning in the mid 1980's, there were signs of state level movement in the direction of states attempting long-term care policies on their own. In the inflationary cycle of the late 1970 's, many state governments were in severe financial jeopardy because of the burden of matching federal Medicaid expenditures, and several states were rumored to be on the verge of bankruptcy at the time.

Federal research and policy in the 1980's became increasingly preoccupied with issues of cost containment and less interested in substantive policy issues. A proposal for a "Title XXI" to provide federal support for personal care was stillborn, and the wave of tax-cutting and program elimination which accompanied the first Reagan administration made it clear that little in the way of leadership on aging issues would be forthcoming from the federal government during the 1980's.

Federal inattention, however, did not make the tremendous pressures of a growing aging population, and the fiscal pressures of exploding health care costs of the aged were compounded by double digit inflation in the late 1970's In the decade of the 1980's, a number of states began to independently plan community based and comprehensive "long-term care" reforms designed to meet future needs within the increasingly restrictive federal fiscal environment. The long term impact of this on state aging services networks may turn out to be substantial. Alter (1988) suggests that integration of Medicaid programs with the Aging Network funded by AOA is already changing the structure of community based elderly services. The resulting second generation system serves a larger volume of clients because it is more centralized, differentiated and formalized and smaller in size. 


\section{Housing Policy}

One of the interesting planning systems which arose in the 1960's only to virtually disappear by the early 1980's was the network of urban planners working on the design and construction of special housing for the elderly. By the late 1970's, public housing projects for the elderly, which was popular with urban residents and big city political forces had virtually replaced less popular and controversial public housing for AFDC families. When a large number of HUD-funded programs were consolidated in the early 1980's, public housing for the elderly was effectively erased from the HUD agenda along with the rest of the federal housing effort.

\section{Planning Technology}

As noted above, social planning was not a method. This does not mean, however, there there are not specific techniques which are frequently employed by the social planner. It would appear that there is such a technology at least in the sense of a more or less ad hoc, experience-tested accumulation of techniques which can be usefully applied in various social planning contexts. (Morris, 1970, Zweig and Morris, 1966) In the remainder of this chapter, we will examine a range of such techniques.

In an early essay on "Rational Control in Social Life", W.I. Thomas spoke of "ordering and forbidding" techniques as the oldest forms of social intervention (Janowitz, 1966). The application of such "regulatory" techniques to problems of public health, child labor and other fields may be the signature of the Progressive era legacy of social planning by the reform darwinists. At the same time, one of the legacies of New Deal planning would certainly be the development of large scale, bureaucratic organizations, such as state departments of public welfare, which incorporated individual problem-solving into their rules and routines. Along with this trend, of course, came the gradual discovery of the repertory of organizational techniques and strategies such as constituency development, goal displacement, and cooptation (Selznick, 1949).

Contemporary planning technologies can be divided into two broad categories, which Gurin and Perlman labeled "analytic techniques" (e.g., needs assessment) and "interactional techniques" (e.g., cooptation) (Perlman and Gurin, 1972). In the first category are the various techniques used in analyzing situations, client groups and problems. In the second category would be various strategies for facilitating the planning process. The analytic techniques of social planning can also be further categorized by the stages of the planning process in which they are most likely to be used.

For this purpose below, we will utilize Hyman's 6-stage model, and divide the planning process into the stages of needs assessment, resource analysis, alternatives, priorities, implementation and evaluation (Hyman, 1976). Only the first two of these will be examined here because of space limitations and 
also because planning techniques for generating alternatives and determining priorities are much less standardized and in general use. Finally, evaluation techniques are the topic of a separate chapter in this volume, Evaluating Programs for Older People.

\section{Needs Assessment}

Needs Assessment is a generic term used to describe a range of problemsolving activities used when the principal practice problem is defining, assessing or estimating the characteristics of a social problem experienced by a given population. Such efforts are ordinarily seen as the initial stage of most problem-solving, decision-making and planning models. Needs assessments may involve either encyclopedic attempts to identify the full scope of age-related needs through use of an instrument like OARS, or they may involve highly selective and targeted investigations. Iutcovich and Iutcovich (1988) for example, examined the transportation needs of the elderly. Following Hyman (1978) further, we can divide analytical needs assessment techniques into five basic types: Key Informant; Commission/Study Panel; Rates Under Treatment (Unmet Needs Measurement); Census Data/Social Indicators and Survey.

Among the interactional needs assessment techniques, Nominal Group Process (Van, Delbecq \& Gustafson, 1975) might be employed with either key informants or commission/study panels. Such panels might also be constituted as small, informal study groups, large public forms, or even formal public hearings. The process for the White House Conferences on Aging in 1950, 1960 and 1970 incorporated a commission/study panel model. (Vinyard, 1979) When the key informants are recognized as experts on the need or issue in question, the Delphi technique may be especially suitable.

Analytically, rates-under-treatment information is most likely to be generated from synthesis of agency case records. Annual reports, planning studies and research data are also somewhat less likely sources of information.

Census type information may come either from institutional census reports, (e.g., the kind of tables published regularly on higher education in the Chronicle of Higher Education). Comparable institutional census data on human services activity is relatively rare in human services, although it may sometimes be available (as in the case of state human services program data in such categories as AFDC and Food Stamps). The most likely source of census data are the various Censuses conducted by the U.S. Bureau of the Census. The census of population is conducted every 10 years. Interesting data on nonprofit agencies may be available through the U.S. Census of Services, conducted every five years, in years ending in 2 and 7. 
In addition to needs assessment, per se, there are a number of alternative analytical protocols available which cover much of the same territory. Reiner, Reimer and Reiner, (1968) for example, make an interesting and useful distinction between client groups and client populations in their proposal for "Client Analysis". At the level of policy planning and analysis, Rivlin (1971) has outlined a fairly complete model she terms simply "Systematic Thinking." Where areal and geographic factors are a major consideration, Social Area Analysis (Shevky and Bell, 1955) may be an appropriate model. Trend Analysis has also been shown to be a useful approach in cases where timerelated changes are of central importance. (Meehan, Lohmann and Locke, 1984). When the issues involve interorganizational relations, input-output models may be useful (Lohmann, 1976). Detailed examination of organizational dynamics may be approached from a number of perspectives, including Goals Analysis (Perrow, 1974) and simulation or modeling activities.

SIMCITY is a popular computer game, for example, that provides a fascinating medium for simulating aspects of city and/or neighborhood dynamics which might be applied to some aspects of neighborhood relocation questions in aging planning. General simulation models, such as the one-line and multi-line cafeteria models might be usefully applied to many aspects of aging service problems.

Mushkat (1985) argues that planners have been preoccupied with methods of estimating the demand for social services and have given little attention to the problem of assessing the supply of services. As a result, they are far better equipped to deal with the magnitude of need than with the capacity to satisfy need.

Social planners have, in some instances, tended to slight the use of qualitative methods. However, narrative descriptions of the action operation of service delivery systems, case studies, policy reviews and legislative histories all have potential applications in social planning for the aged. Maldonado (1985), for example, places the public policy treatment of the hispanic elderly in an explicitly historical context. In conducting needs assessments, social planners also generally tend to avoid legal documents and research strategies. (By contrast, see Lammers and Klingman, 1986) In cases where there has been extensive litigation, depositions and friend-of-thecourt briefs, trial transcripts, rulings and court orders can be fascinating and useful sources of information.

All other approaches to needs assessment pale, however, in comparison with the popularity of the survey as an instrument for conducting a needs study. Garcia (1985) illustrates the use of such a survey with the Hispanic elderly of Tampa Bay Florida. John (1988) details the use of statistical cluster analysis techniques with survey results. 
Insufficient attention is also paid at times to the effective presentation of needs assessment information. A broad range of desktop publishing and presentation software is available for all types of professional computers and workstations today to facilitate the preparation of data tables, maps, charts, diagrams, flow charts and assorted other types of presentations.

\section{Resource Analysis}

Interactional techniques of resource analysis generally revolve around telephone and face-to-face interviews of professionals, public officials, board members and others for purposes of generating timely and accurate information on available resources and gaps in existing services. Questionnaire surveys, inventories and fill-in-the-blank interview schedules are often useful analytical supplements to such information gathering techniques. Constructing questionnaire surveys, however, which capture the appropriate level of detail regarding the actual dovetailing of services as they actually operate (and not just the way they are supposed to function) can be a daunting task.

Students of social planning may be are accustomed to thinking of resource analysis only in terms of gaps in service. Resource analysis may also be used to identify significant developments in the organization's environment which may affect the feasibility of the planning endeavor (Morris and Binstock, 1966).

Techniques borrowed from strategic planning in business called the "environmental scan" can be readily and usefully applied to resource analysis in aging planning. Such scans may involve reviews of professional literature, summaries of items appearing in newspaper or periodical literature, summary tables listing brief abstracts of actual programs operating in a given area or a broad range of other similar devices.

Such scans may also involve close examination of the interactional environment of the organization. Advocates of strategic planning, in particular, have given a good deal of attention to identifying and categorizing the constituencies or "publics" to which a program or service must respond. In an earlier discussion of this question, Dahl (1960) constructs the issue in explicitly political terms as "Community Influence Analysis." More recently, the importance of the community has been gradually minimized and the strategic position of the organization emphasized (Hudson, 1974). Lauffer, for example, terms a similar process "marketing" and identifies six key publics of an organization: consumers, legitimators, resource suppliers, partners in service delivery, staff and policy makers (Lauffer, 1986). The community planning perspective has not been entirely abandoned, however. Preston and Guseman (1979) examined the reasons for overlap between different measures of community leadership. Brilliant (1986) traces the decline of communty wide planning councils during the past two decades and examines 
five current models of community planning and problem-solving and argues for more social work involvement in each.

One of the standard forms of resource analysis in social planning is the program or service inventory, often presented in the form of a service directory or resource listing. Such inventories, built upon a miriad of discrete facts like names and phone numbers are expensive to compile and extremely difficult to keep updated. Although they can be highly useful for service workers, they seldom provide much useful planning information and are often a kind of by-product of social planning efforts.

A major issue in the performance of social resource analysis involves the classification of programs and services. The UWASIS classification system created by Russy Sumariwalla and his associates for United Way of America is a useful scheme for classifying human services by goal (United Way of America, 1976). More recently, Sumariwalla and other members of a planning group for Independent Sector have devised an ingenious alphanumeric classification system for the nonprofit/voluntary/independent sector. McCaslin and Golant have recently suggested a typlogy of agingspecific services (McCaslin and Golant, 1990).

\section{Alternatives}

Interactional and analytic techniques for generating alternatives tend to fall into at least two broad classes: change-oriented techniques are directed at generating new, novel or unprecedented and innovative alternatives, whereas tradition-oriented techniques are directed at identifying tested, workable alternatives already in use elsewhere. Despite the rhetorical patina of change surrounding social planning, much actual work on identification of alternatives is relatively traditional, oriented to examining solutions to problems already in place in other, comparable communities.

A major issue in the identification of alternatives in all forms of planning is the question of when to stop. In general, what Braybrook and Lindblom calls the "synoptic" approach of economists and others suggests that full rationality demands identification of all possible alternatives (Braybrook and Lindblom, 1963). In contrast, Lindblom's approach, labeled variously "incrementalism", "disjointed incrementalism" and more recently "strategic analysis" places planning and policy analysis in its explicit historical context and provide guidelines for limited --incremental, remedial and serial -consideration of alternatives (Lindblom, 1959; Braybrooke and Lindblom, 1963; Lindblom, 1979).

A related line of analysis is Simon's suggestion that the actual behavior of planners and decision-makers might be characterized as involving what he termed "satisficing" - serial review of alternatives which is terminated when 
the first fully acceptable solution is arrived at (Simon, 1976). A number of social planners have sought to refine and improve upon Lindblom and Simon without generating much of any lasting interest. In general, consideration of alternatives in contemporary social planning tends to be characterized by relatively limited attention to the deliberate generation of alternatives and behavior approximating that described by Lindblom and Simon. In particular, the use of field tests, simulations, pilot projects, demonstration projects and scenario writing--all of which are used to generate alternatives in various other fields--are used only infrequently in the social planning context at the agency and community level.

\section{Priority Determination}

Even more neglected is the systematic attention to interactional and analytic techniques in the area of priority determination in social planning. Quite frequently today, calls for "needs assessment" in the context of community concern for age-related and other social problems are actually pointing to the need for priority determination. When funding is cut, when decisions over allocating limited funds must be made, and in other circumstances, simply adding to the already-overwhelming stock of known needs will do little to solve this problem.

The most critical question in contemporary social welfare decision-making at all levels is how to "prioritize" or, rank in priority order, existing needs and feasible alternatives. In the brief interlude of relatively abundant federal funding in the late 1960's through the mid 1970's, such decisions were made on a highly centralized basis and community and state decision-makers became comfortable merely responding to federal mandates and guidelines. While circumstances today are dramatically different, social planning and decision-making rhetoric has not fully adjusted to the changes which have occurred.

One aspect of the priority determination question involves the criteria to use in making such determinations. Nancy Lohmann (1989) suggests the use of Life Satisfaction Scales as a policy-relevant criterion. The OARS (Older Adult Resources and Services) Model can also be applied to the priority problem in planning as a uni-dimensional scale for ranking problem cases or individuals (https://sites.duke.edu/centerforaging/services/older-americansresources-and-services/). In focussing the issue on individuals, however, the difficult problem of which problems are greater is downplayed: Are mental health needs greater or lesser than social needs?

The critical issue in priority determination is who should decide what priorities will be: agency administrators, supervisors, workers, legislators, clients, community residents or others? A characteristic approach, which does more to disguise this issue than to answer it, is to seek refuge in a 
distribution formula. This is the approach of Congress in the GrahamRudman-Latta approach to the federal budget deficit, and it is also commonly employed by aging network agencies.

An important related issue is the response of the minority whose priorities were not adopted. In a fully functional priority-setting system, one could expect that all (or at least most) of those involved would recognize the legitimacy of the result and adopt the resultant priorities as their own. In the current climate of agency, program and client advocacy and interest group activity, however, this seldom (if ever) occurs, and adoption of any set of social priorities at any level is most likely to signal the beginning of a new round of overt and covert efforts to modify them.

\section{Implementation}

Implementation is a topic in which social planning shades over into social administration. In fact, much of the best of the contemporary literature on implementation, or as it is often termed by social workers "program development" is to be found in the social administration literature. This is not particularly surprising, since social planning and social administration tend to be lumped together as "macro methods" in many of the schools of social work and agencies where the producers of this literature practice.

In the implementation of social planning outcomes through interactional techniques, one might reasonably expect the skills of social workers to really shine. Regretably, this is seldom the case. A broad range of practical, common-sense techniques for personal consultation with key actors; staff, client and public information meetings; public education campaigns; press conferences and briefings; are all-too-often ignored or badly handled.

Surprisingly, the record is often considerably better in the area of analytical techniques of implementation. In particular, the current literature documents the use of organization charts, work programs, policy and procedure manuals, information systems, task analyses and job descriptions, scheduling procedures (including PERT and GANTT charts), staff training plans any many other analytical techniques to be applied to the problems of implementing a planned decision.

Taietz (1975) take a novel approach to the issue of implementation by suggesting a community development approach to aging service development, in which more fundamental services are expected to precede others which are partially dependent upon them. Empirical test in one state suggested that the development of aging services corresponded with this approach (Lohmann and $\mathrm{Wu}, 1980$ ). 


\section{Evaluation}

Three quite distinct approaches to evaluation flow in and out of the planning literature. On the one hand, there are the applications of social and behavioral research methodology to the task of program evaluation. In an era of rather severe limits on the availablity of public funds, it is perhaps not surprising that the social-behavioral model of evaluation --which can be quite expensive to implement -- has had less impact on social planning than other models.

A second, quite distinct (and limited) approach, involves the examination of goals and policy of an organization (Perrow, 1974; McCaslin and Golant, 1990). The third approach involves the application of some variant of costbenefit or cost-effectiveness methodology, around which an enormous literature far to vast to cite here has been been built up.

\section{Conclusion}

Social planning has gone from an early emphasis on community as the modal point to an emphasis on public policy planning at the state and federal level and recently to an emphasis on organizational issues and initiatives. Social planning has been a primary tool in the long-term development of new institutions and practices brought about by the unprecendented increases in the size of the aged population. There is every reason to believe that these trends will continue, and that some social work practitioners will be involved in this complex and exciting process. 


\section{References}

Alter, C.F. The Changing Structure of Elderly Service Delivery Systems. Gerontologist. 28. 1. (Feb, 1988). 91-98.

Bauer, Raymond, Editor. Social Indicators. New York. 1963

Bennis, Warren G., Kenneth D. Benne, Robert Chin and Kenneth E. Corey, Eds. The Planning of Change. Third Edition. New York: Holt, Rinehart and Winston. 1976.

Binstock, Robert H. What Sets the Goals for Community Planning for the Aged? The Gerontologist. 7. 1. (1967). 44-46.

Bloedorn, Jack C., Elizabeth B. MacLatchie, William Friedlander and J.M. Wedemeyer. Designing Social Service Systems. Fred M. Cox, John L. Erlich, Jack Rothman, John E. Tropman, eds. Tactics and Techniques of Community Practice. Itasca IL: F.E. Peacock Publishers. 1977. 81-104.

Braybrooke, David and Charles Lindblom. A Strategy of Decision. New York: Free Press. 1963.

Brilliant, Elearnor L. Community Planning and Community Problem solving: Past Present and Future. Social Service Review. 60. 4. (1986) 568-589.

Commager, Henry Steele, Ed. Lester Ward and the Welfare State. Indianapolis IN: Bobbs Merrill. 1967.

Cox, Fred M., John L. Erlich, Jack Rothman and John E. Tropman. Strategies of Community Organization. Third Edition. Itasca, IL: F.E. Peacock. 1979.

Cox, Fred M., John L. Erlich, Jack Rothman and John E. Tropman. Tactics and Techniques of Community Practice. Itasca, IL: F.E. Peacock. 1977.

Dahl, Robert A. The Analysis of Influence in Local Communities. Social Science and Community Action. Charles R. Adrian, Editor. Institute for Community Development and Services. East Lansing MI: Michigan State Univ. 1960

Deegan, Mary Jo. Jane Addams and the Men of the Chicago School. New Brunswick NJ: Transaction Books. 1988.

Dewey, John. How We Think. New York. 1933.

Dror, Yeheskel. The Planning Process: A Facet Design. International Review of Administrative Sciences. 29. 1. (1963) 44-58.

Ecklin, Joan L. and Armand Lauffer. Community Organizers and Social Planners. New York: John Wiley and Sons and Council on Social Work Education. 1972. 
Frieden, Bernard and Robert Morris, Eds. Urban Planning and Social Policy. New York: Basic Books. 1968

Friedmann, John. Retracking America: A Transactive Theory Of Planning. New York: Anchor Doubleday. 1973

Friedmann, Milton. Capitalism and Freedom. 1962

Garcia, Juanita L. A Needs Assessment of Elderly Hispanics in an Inner City Senior Citizen Complex: Implications for Practice. Journal of Applied Gerontology. 4. 1. (September, 1985) 72-85.

Gilbert, Neil. The Design of Community Planning Structures. Social Service Review. 53.4. (1979) 644-654.

Glenn, John, Lilian E. Brandt and F. Emerson Andrews. Russell Sage Foundation, 1907-1946. New York: Russell Sage Foundation. 1947.

Granahan, David B., et. al. Social and Economic Characteristics of the Population in Metro and Nonmetro Counties, 1970-1980. US Department of Agriculture, Economic Research Service. Washington DC: U.S. Govermment Printing Office. 1986.

Hansen, Niles M. A Review of the Appalachian Regional Commission Program. Austin: Univ. of Texas Press. 1969

Harper, E.B. and Dunham, Arthur. Community Organization In Action: Basic Literature \& Critical Comments. New York: Association Press. 1959.

Hawley, E. W. (1974). Herbert Hoover, the Commerce Secretariat, and the Vision of an "Associative State," 1921-1928. The Journal of American History, 116-140. Retrieved from http://www.trinityhistory.org/AmH/Hawley-Hoover.pdf

Hawley, E. W. (1977). Herbert Hoover, the Commerce Secretariat, and the vision of an 'Associative State'. In E. J. Perkins (Ed.), Men and Organizations: The American Economy in the Twentieth Century. New York: G.P. Putnam's Sons.

Hayek, F. A. Individualism and Economic Order Chicago: University of Chicago Press, (1948).

Hayek, F. A. V., \& Caldwell, B. (2007 [1944]). The road to serfdom : text and documents (Definitive ed.). [Chicago]: University of Chicago Press.

Health and Welfare Council of Philadelphia. The Resources - Needs Study. Philadelphia PA:The Council. 1956.

Hudson, Robert B. Rational Planning and Organizational Imperatives: Prospects for Area Agencies on Aging. Annals of the American Academy of Political and Social Science. 1974. 415. 41-54. 
Hyman, Herbert H. Health Planning Methods. Germantown MD: Aspen Systems Corp. 1978.

Hyman, Herbert H. Health Planning: A Systematic Approach. Germantown MD: Aspen Systems Corp. 1976.

Iutcovich, Joyce M. and Mark Iutcovich. "Assessing the Transportation Needs of Pennsylvania's Elderly Population. Journal of Applied Gerontology. 7.4. (December, 1988). 514-529.

Janowitz, Morris, ed. Rational Control of Social Life. Thomas On Social Organization and Social Personality. Chicago: University of Chicago Press. 1966.

John, Robert. "Use of Cluster Analysis in Social Service Planning: A Case Study of Laguna Pueblo Elders." Journal of Applied Gerontology. 7. 1. (March, 1988) 21-36.

Kahn, Alfred. Theory and Practice of Social Planning. New York: Russell Sage Foundation. 1969.

Krout, John A. "The Organizational Characteristics of Senior Centers in America." Journal of Applied Gerontology. 3. 2. (December, 1984) 192-205.

Lammers, William W. and David Klingman. Family Responsibility Laws and State Politics: Empirical Patterns and Policy Implications. Journal of Applied Gerontology. 5.1. (July, 1986) 5-25.

Lauffer, Armand. Social Planning at the Community Level. Englewood Cliffs NJ: Prentice Hall. 1978.

Lauffer, Armand. Social Planning in the United States: An Overview and Some Predictions. Fred M. Cox, John L. Erlich, Jack Rothman and John E. Tropman, eds. Strategies of Community Organization. Third Edition. Itasca IL: F.E. Peacock Publishers. 1979. 292-304.

Lauffer, Armand. To Market, To Market: A Nuts \& Bolts Approach to Strategic Planning. Administration in Social Work. 10 4. (1986). 31-40.

Leistritz, F. Larry and Brenda Ekstrom. Social Impact Assessment and Management: Annotated Bibliography. Garland Publishing. New York. 1983.

Lindblom, Charles. Still Muddling, Not Yet Through. Public Administration Review. 39 6. 1979. 517-526.

Lindblom, Charles. The Science of Muddling Through. Public Administration Review. 19. 1. 1959. 79-88.

Lohmann, Nancy. Service Providers and Life Satisfaction. 8 1. (March, 1989) 8-17. 
Lohmann, Roger A. and Paul Wu. The Hierarchy of Aging Services: A Replication Study. Paper Presented at the Fifth Annual National Conference on Social Work in Rural Areas. 1980. https://researchrepository.wvu.edu/faculty publications/

Lohmann, Roger A. Comprehensive What? Coordination of Whom? Rural AAA's and the Planning Mandate. Journal of Applied Gerontology. 1. (1982) 126-140.

Lohmann, Roger A. Determinants of Old Age Assistance in the American States. Humanics. (December, 1977). https://researchrepository.wvu.edu/faculty_publications/1718

Lohmann, Roger A. Matrix Analysis and Social Planning. (mimeo) 1976.

Lohmann, Roger A. Planning for Aging Services: Implications of Recent Amendments to the Older Americans Act. Paper presented at the Annual Meeting, Gerontological Society of America, 1981. https://researchrepository.wvu.edu/faculty publications/1125

Lohmann, Roger A. Symbolic Interaction and Social Planning: Perspectives from the Early Years. Paper presented at the Second Annual SSI Research Symposium. 1978. https://researchrepository.wvu.edu/faculty publications/868

Lubove, Roy. The Struggle for Social Security, 1900-1935. Cambridge, Mass: Harvard University Press. 1968.

Machen, Tibor R. Beyond Hayek: A Critique of Central Planning. (Online article at Foundation for Economic Freedom web site.) June 1, 1988. https://fee.org/articles/beyond-hayek-a-critique-of-central-planning/

MacKenzie, Norman and Jeanne MacKenzie. The Fabians. New York: Simon and Schuster. 1977.

Maldonado, David Jr. "The Hispanic Elderly: A Socio HIstorical Framework for Public Policy." Journal of Applied Gerontology. 4. 1. (September, 1985) $18-27$.

Marris, Peter and Martin Rein. Dilemmas of Social Change:Poverty and Community Action in the U.S. New York: Atherton Press. 1967.

Mayer, Robert. Policy and Program Planning: A Developmental Perspective. Englewood Cliffs NJ: Prentice Hall. 1985.

Mayer, Robert. Social Planning And Social Change. Englewood Cliffs NJ: Prentice Hall. 1972.

McCaslin, Rosemary and Stephen M. Golant. Assessing Social Welfare Programs for the Elderly: The Specification of Functional Goals. Journal of Applied Gerontology. 9. 1. (March, 1990). 4-19. 
McKillip, Jack. Need Analysis: Tools for Human Services and Education. Newbury Park CA: Sage Publications. 1987.

Meehan, Kevin, Barry Locke and Roger Lohmann. A Model for Human Service Planning. Proceedings of the 10th National Rural Social Work Institute. Columbia MO: Univ. of Missouri SSW. 1984.

Mondale, Walter F. Reporting on the Social State of the Nation. Transaction (June, 1968). 34-35

Morasky, Robert and David Amick. Social System Needs Assessment. Long Range Planning. 11 (April, 1978). 47-54.

Morris, Robert and Robert Binstock. Feasible Planning for Social Change. New York: Columbia Univ. Press. 1966.

Morris, Robert. Is There A Technology of Social Planning? (mimeo). circa 1970.

Mushkat, M. The 'Supply Side' of Social Planning. International Social Work. 28. 3. (1985) 22-34.

Neuber, Keith. Needs Assessment: A Model For Community Planning. Sage. 1980.

Orkin, Susan. "Planning and the Balancing of Interests in an Arean Agency On Aging. Journal of Gerontological Social Work. 2.2. (Winter, 1979). 147160.

Orshansky, Mollie. Counting the Poor: Another Look at the Poverty Profile. Social Security Bulletin. 28. 1. ( January 1965) 3-25

Perlman, Robert and Arnold Gurin. Community Organization and Social Planning. New York: Council on Social Work Education and John Wiley and Sons. 1972.

Perrow, Charles. The Analysis Of Goals In Complex Organizations. Human Service Organizations: A Book Of Readings. Yeheskel Hasenfeld and Richard English, Editors. Ann Arbor MI: University of Michigan Press. 1974. 214-229

Powell, Amy S. The Family Welfare Agency: Community Planning for the Aged. Geriatrics. 5. 5. Sept.-Oct. 1950. 288-291.

Preston, J.D. and Guseman, P.B. A Comparison of the findings of different methods of identifying community leaders. Journal of the Community Development Society. 10. 2. (1979) 51-62.

Puglisi, J. Thomas, Beverly Patnaik, William J. McCoy and Jane A. Begole. "A Needs Assessment of Older Persons." Journal of Applied Gerontology. 2. (1983) 116-118. 
Reiner, Janet, Everett Reimer and Thomas A. Reiner. Client Analysis and the Planning of Public Programs. Bernard Frieden and Robert Morris, Eds. Urban Planning and Social Policy. New York: Basic Books. 1968. 377-395.

Rivlin, Alice. Strategic Thinking for Social Action. Washington DC: Brookings Institution. 1971.

Ross, Peggy J., Herman Bluestone and Fred K. Hines. "Indexes and Rankings for Indicators of Social Well Being for U.S. counties." Springfield VA:U.S. Dept. of Agriculture, Economics, Statistics and Cooperatives Service. 1979.

Ross, Peggy J., Herman Bluestone and Fred K. Hines. Indicators of Social Well-Being for U.S. Counties. Washington DC: U.S. Govermment Printing Office. 1979.

Rothman, Jack. Analysis of Goals and Roles in Community Organization Practice. Social Work. 9.2. April, 1964

Rothman, Jack. Planning and Organizing for Social Change: Action Principles from Social Science Research. New York: Columbia University Press. 1974.

Rothman, Jack. Three Models of Community Organization Practice: Their Mixing and Phasing. Strategies of Community Organization. Fred Cox, John L. Erlich, Jack Rothman and John E. Tropman, Editors. Itasca, IL: F.E. Peacock Publishers. 1979.

Selden, D. R. (1995). Case management in the managed care environment: Keystone to integrated service delivery. Behavioral Healthcare Tomorrow, 4(6), 36.

Selznick, Philip. Leadership in Administration. Evanston IL: Row and Peterson. 1953.

Selznick, Philip. TVA and the Grassroots: A Study in The Sociology of Organizations. Berkeley CA: University of California Press. 1949.

Shevky, E. and Bell, W. Social Area Analysis. American J. of Sociology. 61. 3. 1955.

Simon, Herbert. Administration: A Decision-making Approach. Third Edition. 1976.

Spiegel, Allen D. and Herbert H. Hyman. Basic Health Planning Methods. Aspen Systems Corp: Germantown MD. 1978.

Stefl, M. E. Community Surveys in Local Needs Assessment Projects: Lessons From a Case Study. Administration in Mental Health. 12. 2. 1984. 110-22.

Streib, Gordon. "TVA: A Model Project for These Times." Journal of Applied Gerontology. 3. 2. (December, 1984) 117-124. 
Taietz, P. Community Facilities and Social Services. Atchley R. C. and T. O. Byerts, Eds. Rural Enviroment and Aging. Washington DC:

Gerontological Society of America. 1975. 145-156.

Towle, Charlotte. Common Human Needs. NASW. New York. 1957.

Tropman, Elmer J. Staffing Committees and Studies. Fred M. Cox, John L.

Erlich, Jack Rothman, John E. Tropman, eds. Tactics and Techniques of

Community Practice. Itasca IL: F.E. Peacock Publishers. 1977. 105-111.

U.S. Commission on Rural Poverty. The People Left Behind. Washington DC:

U.S. Government Printing Office. 1965.

United Way of America. UWASIS II. Alexandria VA: United Way of America. 1976.

Van Kleeck, Mary. "Social Planning and Social Work." Proceedings of the National Conference of Social Work. 1932. (Reprinted in Fern Lowry, Readings in Social Case Work, 1920-1938. Columbia University Press. 1939.)

Van, A. L., \& Delbecq Andrew H., D. V. D., H. Gustafson. (1975). Group techniques for program planning: a guide to nominal group and Delphi processes.

Vinyard, Dale. White House Conferences on Aging. Social Service Review. 53. 4. (1979). 655-671.

Von Mises, L. (1949). Human action; a treatise on economics. New Haven,: Yale University Press.

Vosberg, William W. and Felice D. Perlmutter. "The Demonstration Project: Politics Amid Professionalism. Human Services at Risk. Felice D. Perlmutter, Ed. Lexington MA: Lexington Books. 1984. 109-126.

Ward, L. F., \& Commager, H. S. (1967). Lester Ward and the welfare state. Indianapolis: Bobbs-Merrill.

Weiner, Jack. Surveying Methods for Determining the Need for Services. Washington DC: Children's Bureau. 1956

Zweig, Frank and Robert Morris. The Social Planning Design Guide. Social Work. 11. 2. (April, 1966) 